\title{
TEMPORAL VARIATIONS OF ISOTOPIC COMPOSITION OF GLACIER-RIVER WATER DURING SUMMER: OBSERVATIONS AT AUSTRE OKSTINDBREEN, OKSTINDAN, NORWAY
}

\author{
By Wilfred H. THEaKstone
}

(Department of Geography, University of Manchester, Manchester M13 9PL, England)

\begin{abstract}
The isotopic composition of river water discharging from the Norwegian glacier, Austre Okstindbreen, in summer varies on both daily and longer-term scales. Most $\delta^{18} \mathrm{O}$ values of samples from the principal river are within the range -12.5 to $-14.0 \%$ Because new snow tends to be relatively depleted of $\delta^{18} \mathrm{O}$, water leaving the glacier early in the summer has low $\delta^{18} \mathrm{O}$ values. Subsequently, values rise as contributions of old snow, glacier ice, and their melt waters, which are isotopically heavier (median $\delta^{18} \mathrm{O}$ values generally above $-12.0 \%$ ) dilute the $\delta^{18} \mathrm{O}$-depleted base-flow component of discharge, a mixture of waters with different histories of formation, storage, and transit. Accumulation-area melting contributes significantly to river discharge. Towards the end of the summer, as surface melting declines, $\delta^{18} \mathrm{O}$ values tend to fall. Between-year differences of within-summer trends reflect differences of development of the glacier's drainage systems. The drainage systems are affected by outbursts from a glacier-dammed lake. During fine weather, $\delta^{18} \mathrm{O}$ variations follow the diurnal cycle of surface melting: they are strongly correlated with, but lag behind, air temperatures. Perturbations during rainfall cannot be explained simply in terms of the isotopic composition of the precipitation, since low values may be associated with isotopically heavy rainfall. Displacement of water previously stored within or below the glacier may account for the anomaly. Contrasts of composition characterize different rivers leaving the glacier, because the relative contributions of various water sources differ.
\end{abstract}

\section{INTRODUCTION}

Pioneering work on Alpine glaciers between 1967 and 1970 indicated that the isotope content of glacier-river water is subject to significant annual variations and, in summer, to daily fluctuations (Behrens and others, 1971). Studies in Austria revealed that the deuterium content of various sources of water (snow, ice, ground water) differed (Ambach and others, 1976; Stichler and Hermann, 1977). The proportions of these sources present in glacier-river water vary with time and, whilst mixing within a glacier's drainage systems tends to cause homogenization (Ambach and others, 1976), it does not eliminate all systematic variations of isotopic composition. In addition to reflecting the changing influences of diverse water sources, these variations are likely to be influenced by the physical characteristics of the drainage system and the flow-routing through them. Consequently, isotopic analyses of glacierriver water should provide information about the temporal and spatial variability of water storage within and beneath a glacier.

Hydrological investigations at the north Norwegian glacier Austre Okstindbreen between 1976 and 1979 indicated that major differences of water outflow occurred in different summers. It was expected that the composition of the water leaving the glacier would be influenced by year-to-year changes of the glacier's hydrological systems. In both 1976 and 1977, a glacier-dammed lake drained through Austre Okstindbreen during the summer field season
(Knudsen, 1978; Theakstone, 1978). Because lake outbursts affect glacier-drainage systems, it was anticipated that future events would result in variations of glacier riverwater quality. Accordingly, a study of the isotope content of glacier-river water was planned, to supplement discharge, conductivity, and water-chemistry observations. Sampling for subsequent isotope analysis has been undertaken each summer since 1980. The results indicate that the river water is isotopically lighter than most of the water sources at the upper surface of this high-latitude glacier, that it is subject to diurnal variations of isotope content in periods of fine weather, and that temporal patterns of isotope variation may differ from one summer to another.

\section{THE STUDY AREA}

Austre Okstindbreen, the largest glacier of the Okstindan area, covers about $14 \mathrm{~km}^{2}$ (Fig. 1). Its accumulation area $\left(11.4 \mathrm{~km}^{2}\right)$, although largely below $1500 \mathrm{~m}$,

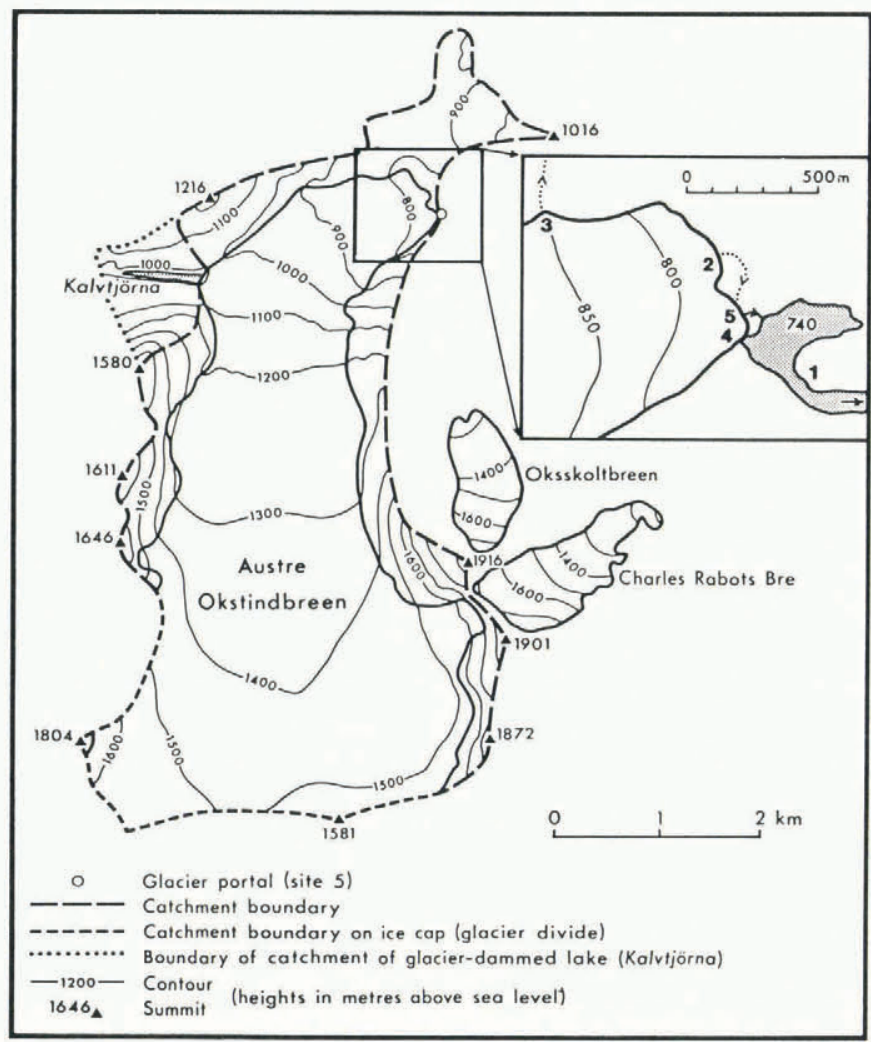

Fig. 1. The glacier Austre Okstindbreen, the catchment within which it lies, and two small adjacent glaciers. When the basin of the glacier-dammed lake Kalvtjörna is full, its catchment is drained westward. During outbursts from the lake, and when the basin is empty, the catchment supplies water to the glacier. Since 1976, water level has been recorded each summer at the site 1 gauging station. 
rises to more than $1700 \mathrm{~m}$ above sea-level. Over much of the area, the depth of winter snow accumulation exceeds $2.5 \mathrm{~m}$; at the highest parts, it can be more than $7 \mathrm{~m}$ (Knudsen, 1987). The mean height of the equilibrium line is close to $1200 \mathrm{~m}$.

The glacier terminates in a small lake, at $740 \mathrm{~m}$. In most summers, two rivers issue from the tongue. The discharge of the northern river generally exceeds that of the southern one (Table I). However, in 1978 and 1981 the southern river was the larger throughout the summer, and in 1985, until mid-July, its discharge again was greater than that of the northern one. On 22 July 1985, the southern river ceased to flow during a storm, and the size of the northern river increased considerably. In 1987, water did not issue from the southern side of the glacier.

Continuous recording of glacier-river water-level variations during successive summer field seasons, monitoring of electrical conductivity, dye-tracer testing, observations of the drainage of the glacier-dammed lake, and sampling of river water for chemical and isotopic analyses (Theakstone, 1986; Theakstone and Durbin, 1986; Reimann, unpublished; Svendsen, unpublished) have provided much information about the glacier's hydrology. Whilst melt water generated at the surface of the ablation area flows rapidly through the

TABLE I. WATER DISCHARGE FROM AUSTRE OKSTINDBREEN, 1976-87 (SITES ARE SHOWN ON THE FIGURE 1 INSERT)

$1976-80$
Water left the glacier at site 3 and flowed northward. The river course was then abandoned when the glacier margin retreated over a low col

Kalvtjörna drained on 31 July -1 August

Kalvtjörna drained on 5 August, water leaving the glacier at site 3

The northern river issued at site 2 , and passed through a small pond, before flowing back beneath the glacier. The river reemerged at site 5

Kalvtjörna drained on 19-20 July

Kalvtjörna drained on 29 July. Some water discharged from site 3 , but most issued at site 2

The southern river, issuing at site 4, was larger than the northern one

The northern river (sites 2 and 5) was larger than the southern one

Until 22 July, the southern river, issuing at site 4 , was slightly larger than the northern one, which left at site 5 . On 22 July, the pond at site 2 drained; since then, no water has left the glacier there. On 22 July, the southern river ceased to flow. For the rest of the summer, water discharge was confined to the northern river (site 5)

The northern river (site 5) was larger than the southern one

Only the northern river (site 5) issued from the glacier. Kalvtjörna drained on 16 July, water leaving the glacier at site 5 glacier from some points of entry (Knighton and Theakstone, 1978), temporary storage of water commonly occurs within the glacier (Theakstone and Knudsen, 1981). Discrete glacier-drainage systems exist. These systems may be disrupted before outbursts from the glacier-dammed lake are registered at the portal through which the river emerges (Knudsen and Theakstone, 1988). The isotopic composition of the river water leaving the glacier in summer varies. These variations, which include both long-term and short-term trends, are discussed in this paper.

Access to Austre Okstindbreen during the winter is difficult, and it has not been possible to obtain samples until towards the end of that season. Snow melt is slight until late May, but much melting normally occurs in June, before the start of summer field seasons at the glacier. At the beginning of the melt season, the principal source of river water is snow which has accumulated in the previous winter. Subsequently, as the altitude of the transient equilibrium line increases, melting ice begins to make a significant contribution to discharge. Rainfall has a marked effect on the glacier-river hydrograph in summer. The basin of the glacier-dammed lake, Kalvtjörna, fills as a result of melting of the winter's snow in May-June. Outbursts from the lake, which have been known to occur in June, July, and August, disrupt the normal pattern of river discharge and have significant consequences for the glacier's drainage systems (Knudsen and Theakstone, 1988). The ablation season normally ends in late August or early September.

\section{METHODS}

Water samples were collected from the northern river issuing from the tongue of Austre Okstindbreen. In 1980 and 1981, only a small number of samples was collected by hand. Between 1982 and 1987, samples were collected at pre-set intervals (Table II) with the aid of an automatic liquid sampler. In 1982 and 1985, water samples were also collected by hand from the southern glacier river. Samples were transferred to randomly selected numbered polyethylene vials and transported to the Geophysical Isotope Laboratory of Copenhagen University for analysis. Samples of glacier ice were collected along $1.6 \mathrm{~km}$ longitudinal traverses from the snout to the lower part of the ice fall in 1985 and 1987 , and a few samples were collected at randomly selected sites in 1986. Samples of old snow were obtained from the walls of pits excavated in the glacier's accumulation area in 1983, 1986, and 1987; in 1983 and 1987, sampling was extended into firn below the previous summer's surface. Additional samples of old snow were collected at various sites between c. 650 and $1650 \mathrm{~m}$ in 1980 and 1985 , and from the accumulation-area surface in 1987. In May 1987, when the entire glacier still was snow-covered, snow samples were collected from pits at 1240 and $800 \mathrm{~m}$. Samples of snow, firn, and ice were allowed to melt in sealed bags before being transferred to vials. Samples of water from supraglacial streams, from melting snow, and from the glacier-dammed lake also were obtained at various times during the summers. A single water sample was collected from the very small stream which was issuing from the glacier on 26 May 1987.

$\delta^{18} \mathrm{O} /{ }^{16} \mathrm{O}$ ratios are presented as $\delta^{18} \mathrm{O}$ values, expressed in relation to the standard mean ratio of ocean water (SMOW):

$$
\delta^{18} \mathrm{O}=\left\{\left(R_{\text {sample }} / R_{\text {SMOW }}\right)-1\right\} \times 1000 \%
$$

where $R$ is the $\delta^{18} \mathrm{O} /{ }^{16} \mathrm{O}$ ratio. In 1985 and 1986 , all samples were analysed twice. The mean difference of the two $\delta^{18} \mathrm{O}$ values of the 582 samples was $0.072 \%$ (range: $0.00-0.28 \%$ ).

The $\delta^{18} \mathrm{O}$ values considered here are summarized in Tables II and III. Although the summary statistics of glacier river-water samples obscure within-summer trends, they are of great utility for between-year comparisons.

\section{THE ISOTOPIC COMPOSITION OF THE COMPONENTS OF BULK DISCHARGE OF THE GLACIER RIVER}

The isotopic composition of glacier ice at Austre Okstindbreen shows no significant change from one year to another. Isotopic fractionation is not normally observed 
TABLE II. EXTREME, QUARTILE, AND MEDIAN $\delta^{18} \mathrm{O}$ VALUES OF WATER SAMPLES COLLECTED FROM THE NORTHERN GLACIER RIVER, AUSTRE OKSTINDBREEN, 1980-87. THE START AND END OF SAMPLING PERIODS ARE INDICATED (MONTH, DAY). WITHIN EACH PERIOD, SAMPLING WAS SUBJECT TO INTERRUPTION BY INSTRUMENT MALFUNCTION, AND OTHER CAUSES. $N$ IS THE NUMBER OF SAMPLES FOR WHICH SUMMARY STATISTICS HAVE BEEN CALCULATED. IN 1985, UNTIL 22 JULY, THE NORTHERN GLACIER RIVER WAS SMALLER THAN THE SOUTHERN ONE (SEE TEXT)

$\begin{array}{lcccccccc}\text { Year } & \text { Minimum } & \begin{array}{c}\text { Lower } \\ \text { quartile }\end{array} & \text { Median } & \begin{array}{c}\text { Upper } \\ \text { quartile }\end{array} & \text { Maximum } & N & \begin{array}{c}\text { Sampling } \\ \text { period }\end{array} & \begin{array}{c}\text { Sampling } \\ \text { interval }\end{array} \\ & & & & & & & & \\ 1980 & -13.64 & -13.19 & -12.97 & -12.82 & -12.37 & 16 & 07.10-08.24 & - \\ 1981 & -12.11 & -11.83 & -11.68 & -11.56 & -10.99 & 20 & 07.13-08.04 & - \\ 1982 & -13.39 & -13.14 & -13.02 & -12.85 & -12.54 & 60 & 07.15-08.19 & 6 \\ 1983 & -13.86 & -13.39 & -13.02 & -12.74 & -11.83 & 240 & 07.01-08.12 & 4 \\ 1984 & -13.73 & -13.45 & -13.34 & -13.13 & -12.41 & 183 & 07.13-08.02 & 2 \\ 1985 & -13.91 & -13.41 & -13.19 & -13.02 & -12.64 & 241 & 07.06-07.22 & 1 \\ 1985 & -14.10 & -13.80 & -13.70 & -13.59 & -13.32 & 106 & 07.22-07.27 & 1 \\ 1986 & -13.25 & -12.87 & -12.72 & -12.56 & -12.02 & 262 & 07.11-07.29 & 2 \\ 1987 & -14.36 & -13.98 & -13.75 & -13.64 & -13.00 & 188 & 07.09-07.29 & 2\end{array}$

TABLE III. RANGE AND MEDIAN $\delta^{18} \mathrm{O}$ VALUES OF WATER-SOURCE SAMPLES COLLECTED AT AUSTRE OKSTINDBREEN, 1980-87

\section{Source}

Glacier ice

Supraglacial streams

Firn (pit)

Old snow (pits, summer)

Old snow (surface)

New snow (pits, May)

Snow-melt water

Rainfall

Glacier-dammed lake

\section{Minimum Median Maximum $N$}

$\begin{array}{rrrr}-12.78 & -11.78 & -10.49 & 27 \\ -12.67 & -11.78 & -10.49 & 20 \\ -10.73 & -10.54 & -10.30 & 17 \\ -12.72 & -11.32 & -10.03 & 78 \\ -15.56 & -12.03 & -11.05 & 12 \\ -17.12 & -12.12 & -9.72 & 17 \\ -13.75 & -11.66 & -10.46 & 11 \\ -15.53 & -10.90 & -6.49 & 23 \\ -13.10 & -12.33 & -12.13 & 9\end{array}$

during melting or sublimation of glacier ice (Moser and Stichler, 1980), and it is not surprising, therefore, that the composition of water in streams flowing over the surface of the lower glacier ("supraglacial streams", Table III) is almost identical with that of the ice.

Since the nature of the snow or rain falling at the glacier reflects the antecedent meteorological conditions and fractionation processes to which the atmospheric water masses have been subjected (Dansgaard, 1964), its isotopic composition may differ both within and between events (Gat, 1980). The range of the $\delta^{18} \mathrm{O}$ values of rainfall collected at and close to Austre Okstindbreen at various times between 1980 and 1987 is very large, some samples being richer in the heavier isotope than is glacier ice, others being depleted (Table III). $\delta^{18} \mathrm{O}$ values of samples of rainfall collected at the field-work base camp $(535 \mathrm{~m})$ on five occasions within the period 24-31 July 1987 differed significantly (Fig. 2). Because air temperature tends to decrease with increasing altitude, and heavy isotope depletion is likely to be greater when the temperature at the time of precipitation is lower, the decrease of $\delta^{18} \mathrm{O}$ values with altitude on 25 July 1987 was not surprising. A

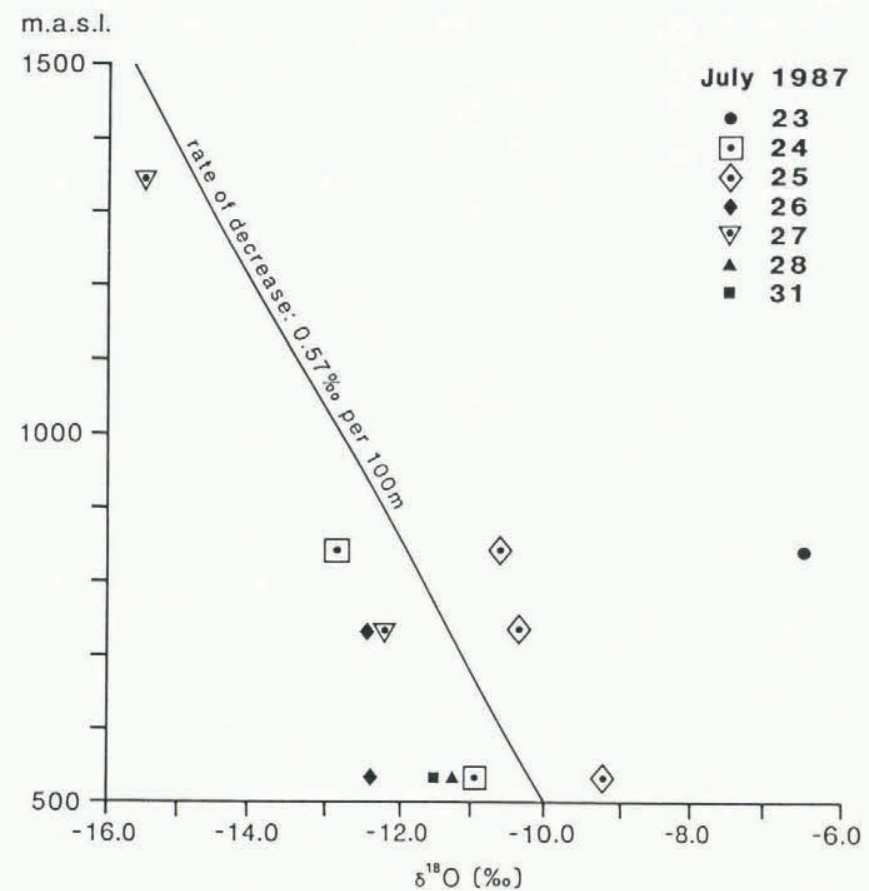

Fig. 2. $\delta^{18} O$ values of rainfall samples collected at and close to Austre Okstindbreen in July 1987. Those for 24. 25 , and 27 July decrease with altitude at a rate close to that represented by the straight line.

similar trend was displayed by samples collected at two of the stations on the previous day, and at altitudes of 740 and $1350 \mathrm{~m}$ on 27 July (Fig. 2). Samples obtained at the two lowest stations on 26 July did not conform to this trend (Fig. 2).

Because isotope separation increases with decreasing temperature, isotopically lighter snow may accumulate on the higher parts of the glacier. Hambrey (1974) reported that, at the glacier Charles Rabots Bre, adjacent to Austre Okstindbreen (Fig. 1), the $\delta^{18} \mathrm{O}$ value of newly fallen snow decreased by $0.6 \%$ per $100 \mathrm{~m}$ increase of altitude. However, the altitudinal effect depends on the local climate and topography: initial spatial patterns of isotope distribution are likely to be modified when winds cause drifting. Sampling 
of snow in late winter has provided some of the lowest $\delta^{18} \mathrm{O}$ values obtained at Austre Okstindbreen, as well as a few unusually high values (Table III). Natural processes cause changes of isotopic composition of fallen snow. In summer, evaporation and melting, occurring at variable rates, lead to near-surface enrichment (Moser and Stichler, 1975), whilst melt-water percolation within accumulated snow, and changes caused by partial recrystallization (Buason, 1972), result in a tendency towards isotopic homogenization (Arnarson, 1981). Overall, the speed and extent of homogenization will depend on factors controlling water percolation. Snow-pit studies indicate that, in the central part of Austre Okstindbreen's accumulation area, it is almost complete within 1 year old firn (Theakstone and Durbin, 1986): the range of $\delta^{18} \mathrm{O}$ values of 17 firn samples between 2.4 and $4.1 \mathrm{~m}$ below the 1982 summer surface was very small (Table III). However, in old snow less than 1 year old, isotope variations, probably resulting from discrete episodes of winter accumulation, are characteristic: in summer, the range of the $\delta^{18} \mathrm{O}$ values is rather similar to that of glacier ice (Table III). Summer sampling of snow surviving from the previous winter at various sites between 600 and $1700 \mathrm{~m}$ above sea-level has yielded a relatively large range of $\delta^{18} \mathrm{O}$ values, as has sampling of melt water leaving snow patches (Table III).

\section{VARIATIONS OF ISOTOPIC COMPOSITION OF GLACIER-RIVER WATER: THE INFLUENCE OF WEATHER CONDITIONS}

In general, ablation-area inputs of water to Austre Okstindbreen have relatively high $\delta^{18} \mathrm{O}$ values: compared with most of the water sources listed in Table III, bulk glacier-river water (Table II) is $8^{18} \mathrm{O}$-depleted. Clearly, the tabulated sources do not account directly for the composition of the water discharging from the glacier - either they are modified by fractionation processes or they are supplemented by water sources which have not been sampled. Neither fractionation processes occurring within, or at the base of, the glacier nor water sources there can be monitored with ease.

For much of the ablation season, the base-flow component of glacier-river discharge at Austre Okstindbreen is diluted by a "rapid-transit" component, which varies diurnally. These variations reflect the generation of melt water by heat inputs at the glacier surface, principally below the altitude of the transient equilibrium line. Although solar radiation is the principal energy input responsible for melting of glacier ice, the variability of net radiation is relatively small (Bendixen, unpublished). Because sensible-heat flux and latent-heat flux contributions are temperature-related, there is a close correlation between air temperature and ablation (Braithwaite and Olesen, 1984).

During extended rain-free periods, melt water from the surface enters Austre Okstindbreen, passes through it and, together with the base-flow component, emerges at the point of outflow of the glacier river. The time taken in transit by the melt water is reflected in a lag between variations of those components of the surface-energy balance responsible for its generation and temporal variations of the $\delta^{18} \mathrm{O}$ value of bulk glacier-river water. In both 1983 and 1984, isotope variations of glacier-river water in periods of fine weather lagged $6 \mathrm{~h}$ behind those of the air temperature recorded $2 \mathrm{~m}$ above the ground surface at the point of emergence of the glacier river (Fig. 3). This lag indicates the mean speed of transit of melt water generated by diurnally varying energy sources. It is an average for the whole of the glacier area from which such melt water is derived, and it is a measure of the organization and storage characteristics of the glacier's drainage system.

In view of the close relationship between air temperature and the isotopic composition of river water in rain-free periods established in previous years, an attempt was made in the first part of the 1985 field season to assess the value of air temperature as a predictor of river-water composition in differing weather conditions. Temperature was recorded every $10 \mathrm{~min}$, using a data logger
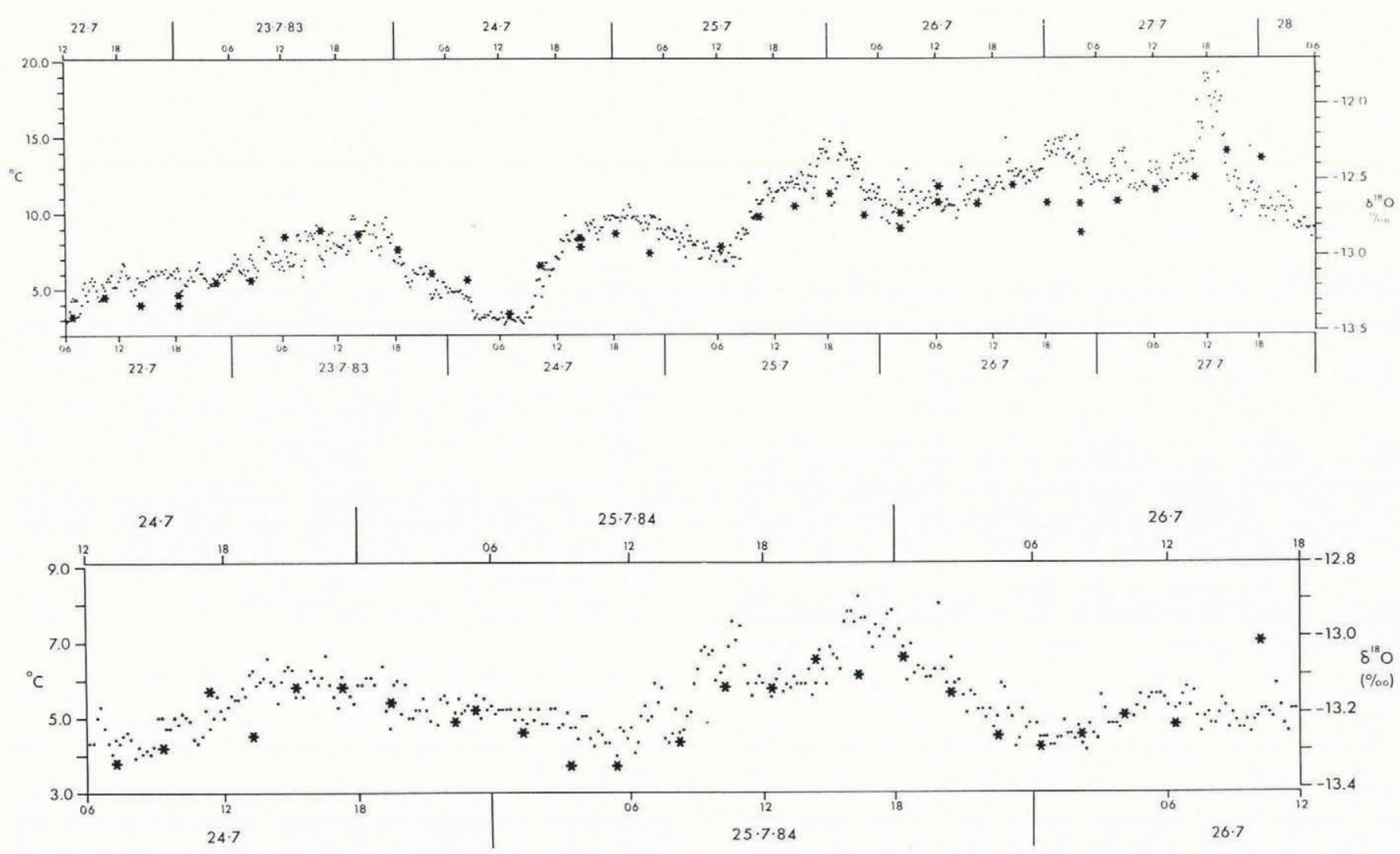

Fig. 3. Air temperatures (dots) recorded every $10 \mathrm{~min} 2 \mathrm{~m}$ above ground level at site 2 (Fig. 1) and $\delta^{18} O$ values of glacier-river water (stars). Data are from periods of dry weather in July 1983 and July 1984. Duplicate samples were collected on five occasions in 1983. Note that time-scales for $8^{18} \mathrm{O}$ values (top) lag $6 \mathrm{~h}$ behind those for air temperatures (bottom). 
adjacent to the water-level recorder at site 2 (Fig. 1) where the river was confined within a bedrock channel. A rating curve could not be established for the site, but records from the previous summer indicated that variations of water level at site 2 relate closely to glacier river-discharge variations (Knudsen and Theakstone, 1988). Whilst the influence of isotopically heavy melting ice on the composition of glacier-river water in fine weather was as apparent in 1985 as in the two preceding summers, marked perturbations resulted when atmospheric conditions changed.

On 9 and 10 July, in fine weather, marked diurnal fluctuations of air temperature were mirrored by the $\delta^{18} \mathrm{O}$ values of water samples, with a lag of about $6 \mathrm{~h}$ (Fig. 4). On 11 July, the lag was shorter and the amplitude of the $\delta^{18} \mathrm{O}$ cycle reduced markedly, with lower maximum values. On $12 \mathrm{July}$, with cloudless skies, the temperature rose from a minimum of $6^{\circ} \mathrm{C}$ at $04.00 \mathrm{~h}$ to $13^{\circ} \mathrm{C}$ at noon. The glacier-river level began to rise quickly at $04.00 \mathrm{~h}$ and $\delta^{18} \mathrm{O}$ values increased from around $10.00 \mathrm{~h}$. During these first $4 \mathrm{~d}$ of the study, departures from the prevailing fine weather conditions included (A) a brief mid-afternoon cloudy period on $10 \mathrm{July}$, in which air temperature was depressed, (B) a short-lived, but heavy, fall of convective rain at around $19.00 \mathrm{~h}$ on $10 \mathrm{July}$, (C) some rain during the early morning of 11 July, which ceased at $09.30 \mathrm{~h}$, but caused the glacier-river level to begin to rise several hours before the usual time of occurrence of the discharge minimum, and (D) an abrupt, but rather short-lived, change in the early afternoon of 12 July, during which temperatures dropped as some convective rain fell. Reduced ice melt during event A may account for the fact that the water sample collected at $21.50 \mathrm{~h}$ on 10 July was more depleted of ${ }^{18} \mathrm{O}$ than might have been expected. The brief episode B had no apparent major effect on river-water composition, but may have helped maintain discharge at a relatively high level. An anomalous river-water $\delta^{18} \mathrm{O}$ value $(-13.45$ to $-13.49 \%)$ at $08.55 \mathrm{~h}$ on $11 \mathrm{July}$, when rain had been falling for some time, cannot be explained directly by precipitation, since the rain-water samples of event $C$ were isotopically heavy. Rainfall was sampled at the field-work base camp $\left(530 \mathrm{~m}\right.$ a.s.l.) at $09.50 \mathrm{~h}$; it had a $\delta^{18} \mathrm{O}$ value of -8.77 to $-8.79 \%$. Three rain-water samples collected on and close to the glacier (between 750 and $950 \mathrm{~m}$ ) at $11.00 \mathrm{~h}$ had values of -9.62 to $\rightarrow .81 \%,-10.15$ to $-10.16 \%$, and -10.32 to $-10.34 \%$. The release of water from storage within or beneath the glacier, as noted by Van de Griend and Arwert (1983) during a rain storm at the Neves glacier, Italy, might have been responsible for the low $\delta^{18} \mathrm{O}$ value; enhanced sliding resulting from rain water penetrating to the glacier bed may lead to the tapping of previously isolated cavities. Although the isotope record during the afternoon of 12 July lacks detail, a lower-than-expected value $(-12.99$ to $-13.12 \%$ ) was recorded for the sample collected at $16.00 \mathrm{~h}$, suggesting that $\delta^{18} \mathrm{O}$-depleted water was leaving the glacier as a result of event $\mathrm{D}$. This may have reflected a decrease of ice melt, and of its diluting effect on river water.

The weather changed early on 13 July. Rainfall soon after midnight caused a marked increase of river discharge (E, Fig. 5). (Unfortunately, the water-level recorder failed between 06.00 and $12.00 \mathrm{~h}$ and, because of an instrument malfunction, only two water samples were obtained between midnight and $10.00 \mathrm{~h}$.) More heavy rainfall in the afternoon, accompanied by a rapid temperature decline (F, Fig. 5), reduced the rate of glacier-ice melt, but maintained river discharge at a high level. The low range of $\delta^{18} \mathrm{O}$ values

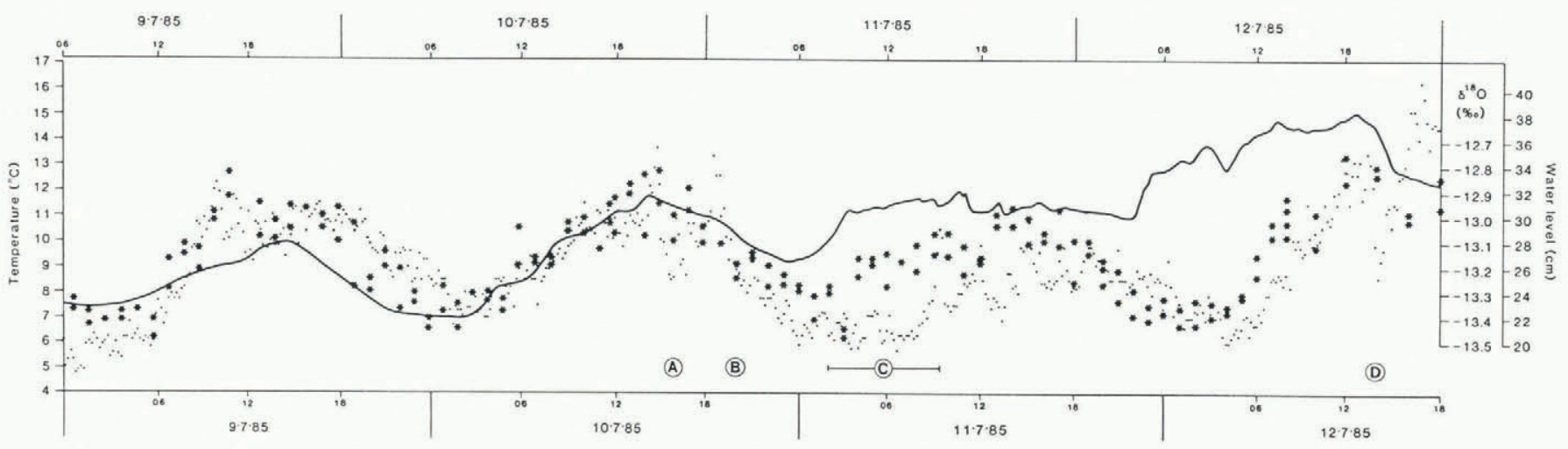

Fig. 4. $\delta^{18} \mathrm{O}$ values of glacier-river water (stars), $2 \mathrm{~m}$ temperatures (dots) at the point of emergence of the river from the glacier (site 2, Fig. 1), and glacier-river level (line), 9-12 July 1985. All samples were analysed twice; where only one star is plotted, the two values coincide. Note that the time-scales for $\delta^{18} \mathrm{O}$ and river level (top) lag $6 \mathrm{~h}$ behind that for air temperature (bottom). Letters $A-D$ (related to the lower time-scale) refer to events discussed in the text.

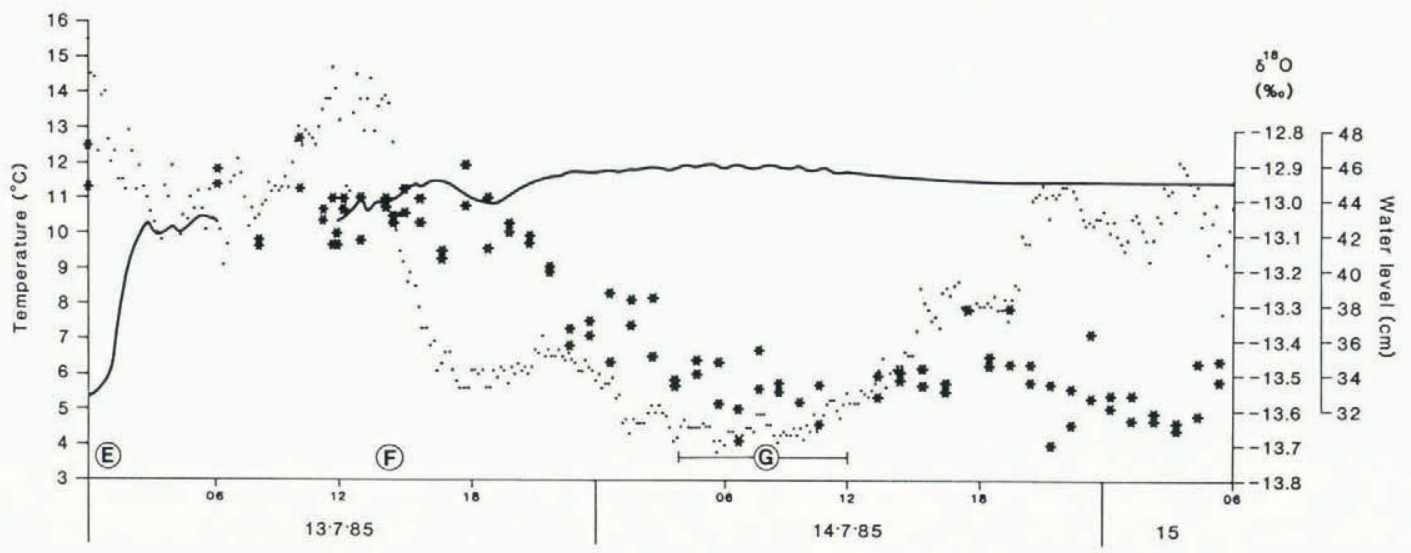

Fig. 5. $\delta^{18} \mathrm{O}$ values of glacier-river water (stars), $2 \mathrm{~m}$ air temperatures at site 2 (dots), and glacier-river level (line), 13-14 July 1985. All samples were analysed twice; where only one star is plotted, the two values coincide. All parameters are plotted on the same time-scale. Letters E-G refer to events discussed in the text. 
between 11.00 and $21.00 \mathrm{~h}$ on 13 July suggests that well-mixed water was issuing from the glacier. During the night of $13-14$ July, much more ${ }^{18} \mathrm{O}$-depleted water left Austre Okstindbreen than had been the case earlier in the study period, when discharge was more variable. Throughout the morning of 14 July (G, Fig. 5), the cloud base was below $800 \mathrm{~m}$. The air temperature remained below $7^{\circ} \mathrm{C}$ for about $24 \mathrm{~h}$, but a rapid improvement of the weather in the afternoon resulted in a sharp rise. Discharge hardly varied throughout the day, and the isotope record resembled that of discharge more closely than that of temperature; although it included a morning minimum and a late-afternoon maximum, the amplitude of the wave was much lower than that of air temperature. The river water was ${ }^{18} \mathrm{O}$-depleted. Despite reduced incident short-wave radiation and air temperatures, and a consequent reduction of ablation, glacier-river discharge remained high.

\section{GENERAL TRENDS OF ISOTOPIC COMPOSITION OF GLACIER-RIVER WATER, JULY AND AUGUST}

Compared with water sources within the ablation area and with rain which falls on to the glacier in summer, the Austre Okstindbreen river is ${ }^{18} \mathrm{O}$-poor (Tables II and III). Diurnal variations of isotopic composition of the river water are superimposed on longer-term trends (Fig. 6). In part, these trends reflect variations of the "base-flow" component of discharge, which may include ground water, water draining from storage zones within the glacier (including water-filled crevasses and cavities), and water from the firn-water aquifer of the accumulation area, supplied by summer-melt processes (Oerter and others, 1985; Röthlisberger and Lang, 1987). They also are likely to reflect the functioning of the glacier's drainage systems. Outbursts from the glacier-dammed lake, Kalvtjörna, affect these systems (Knudsen and Theakstone, 1988). The longer-term trends are apparent when the extreme, median, and quartile $\delta^{18} \mathrm{O}$ values of samples collected over periods of 4 or $5 \mathrm{~d}$ are plotted (Figs $7-11$ ).
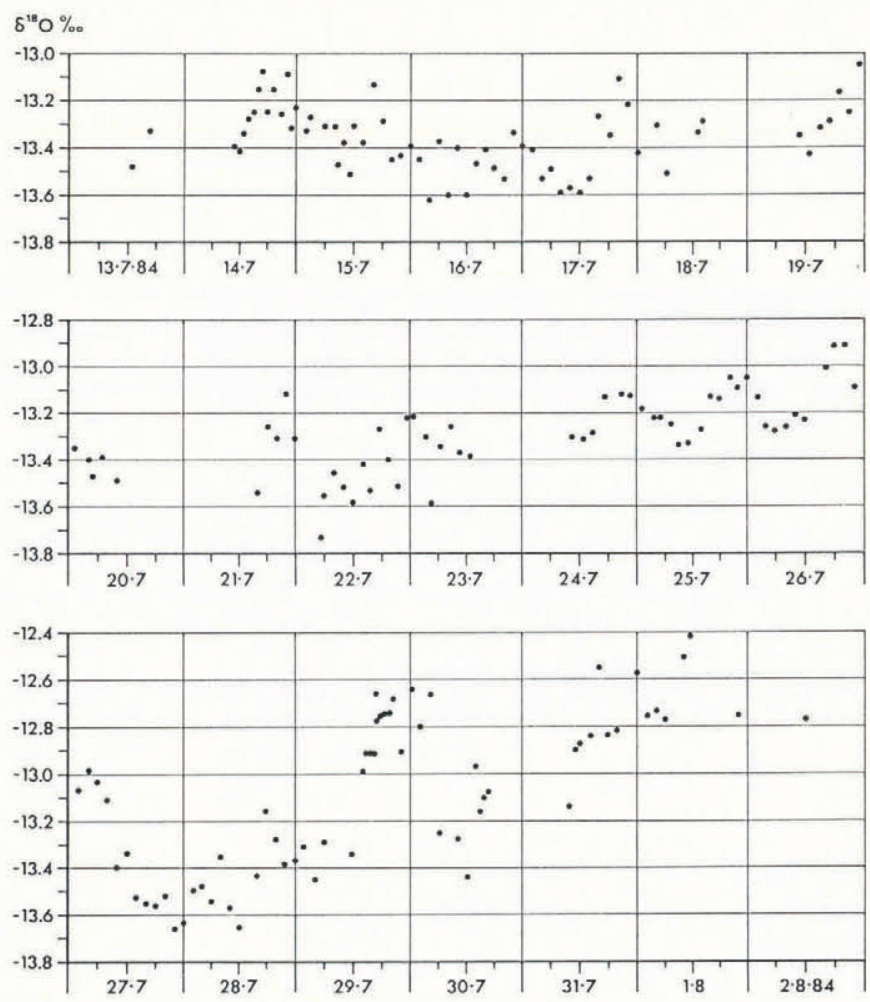

Fig. 6. $\delta^{18} \mathrm{O}$ values of glacier-river water, Austre Okstindbreen, 13 July-2 August 1984. Diurnal variations are superimposed on longer-term trends. The glacier-dammed lake, Kalvtjörna, drained on 29 July.
The annual snow melt in the Okstindan area does not begin until late May or June. When Austre Okstindbreen was visited in May 1986 and May 1987, very little water was issuing from the glacier. The $\delta^{18} \mathrm{O}$ value of a sample collected from the small stream at the snout on 26 May 1987 was $-14.21 \%$, and that of water in a pool at the glacier margin at $760 \mathrm{~m}$ was $-14.19 \%$. At the beginning of the melt season, the principal source of river water is snow which had accumulated in the previous winter. Snow on the glacier snout on 26 May 1987 had a $\delta^{18} \mathrm{O}$ value of $-14.58 \%$. Three samples were collected from the $1.85 \mathrm{~m}$ thick snow cover on the glacier at $800 \mathrm{~m}$; the $\delta^{18} \mathrm{O}$ values were $-15.70 \%$ (snow in contact with glacier ice), $-13.27 \%$ (snow $0.85 \mathrm{~m}$ below the surface), and $-10.06 \%$ (snow at the upper surface). Enrichment of near-surface material in ${ }^{18} \mathrm{O}$ is likely to have resulted from evaporation (Moser and Stichler, 1980). As melt water from the surface infiltrated the snow-pack, the latter also became enriched.

As the ablation season proceeds, fractionation effects gradually lead to a gross increase of the $\delta^{18} \mathrm{O}$ value of the snow cover which remains on the glacier tongue. With the altitude of the transient equilibrium line increasing, melting glacier ice begins to make a significant contribution to discharge. Thus, the $\delta^{18} \mathrm{O}$ values of the river water discharging from the glacier tend to rise. However, some of the water generated at the surface, both above and below the transient equilibrium line, is delayed in transit for a few hours or days, and some is stored within the glacier for several weeks or more. The nature and extent of storage are likely to be affected by the degree to which the glacier's drainage systems have developed. This itself is influenced markedly by the time of drainage of Kalvtjörna (Knudsen and Theakstone, 1988).

As the summer progresses, the increasing efficiency of the glacier's drainage systems enables more water to move through them more quickly although, as shown by dyetracer tests, considerable delays characterize throughflow from many points (Theakstone and Knudsen, 1981). As connections develop between conduits and cavities, and local systems coalesce, areas of the bed not previously connected to a drainage system are tapped, permitting the outflow of water previously stored in unconnected cavities. During storms, when much water is entering the glacier from its surface, drainage-system disruption is likely. Towards the end of the summer, as surface melting declines and river discharge decreases, the increased role of the base-flow component is seen in an overall fall of $\delta^{18} \mathrm{O}$ values.

In 1982, Kalvtjörna drained through Austre Okstindbreen on 19-20 July. Only five samples had been collected from the glacier river for isotope analysis before the event, and none was collected during it. Six samples were collected on 22 and 23 July. The median $\delta^{18} \mathrm{O}$ value of the 11 samples obtained between 15 and 23 July was $-13.00 \%$. That of the 15 samples collected between 24 and 27 July $(-13.05 \%)$ was little different, but subsequently, as glacier ice was exposed increasingly to ablation, the river water became more enriched in the heavy isotope - median and quartile values became less negative (Fig. 7). On the

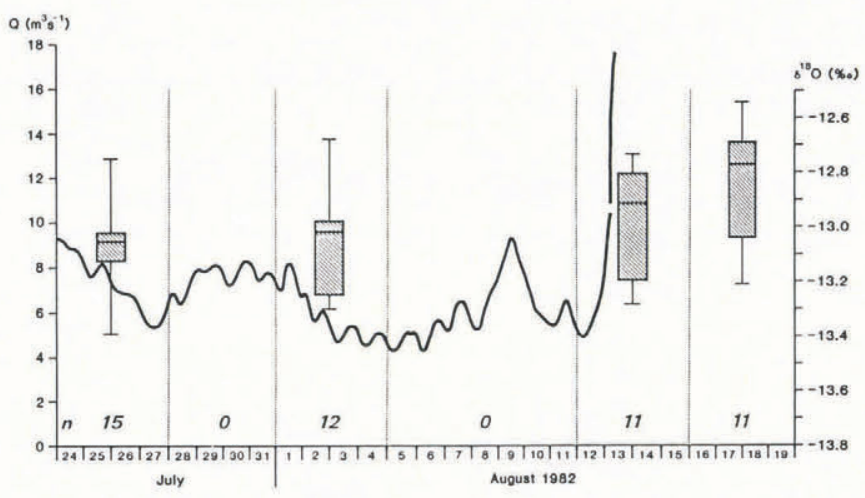

Fig. 7. Glacier-river discharge, and extreme, median, and quartile $\delta^{18} O$ values of glacier river-water samples collected at Austre Okstindbreen during $4 d$ periods in July and August 1982. The number of samples ( $n$ ) within each period is indicated. 


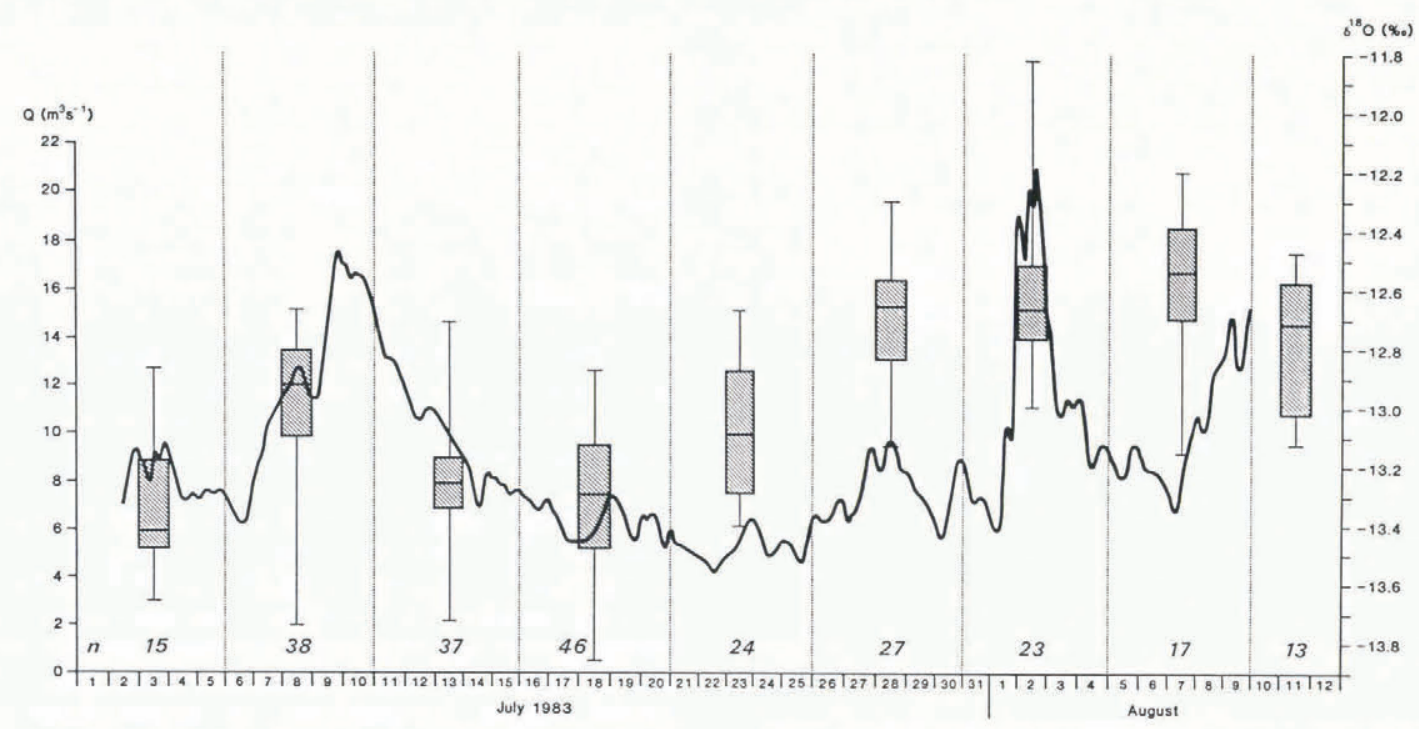

Fig. 8. Glacier-river discharge, and extreme, median, and quartile $\delta^{18} O$ values of glacier river-water samples collected at Austre Okstindbreen during $5 d$ periods in July and August 1983. The number of samples ( $n$ ) within each period is indicated. Note that the last period is of $3 \mathrm{~d}$.

basis of the somewhat limited sampling in 1982, it was concluded that the increasing contribution made to river discharge by glacier ice was responsible for the trend of $8^{18} \mathrm{O}$ values.

In 1983, the Kalvtjörna basin remained full throughout the period of field observations at Austre Okstindbreen. Heavy rain in the second week of July and at the beginning of August caused high river discharge, and both periods were characterized by elevated $\delta^{18} \mathrm{O}$ values (Fig. 8). Generally, however, the trend of $\delta^{18} \mathrm{O}$ variations of the river water in 1983 could be related to observed changes of snow and ice melt. In the early summer, dominated by snow melt, $\delta^{18} \mathrm{O}$ values rose. Subsequently, as the previous winter's snow disappeared from the lower part of the catchment, values declined, but another rise followed as glacier-ice melt increased. When ablation declined in late summer, $\delta^{18} \mathrm{O}$ values fell.

In the 1984 sampling period, an initial slight decline of the median $\delta^{18} \mathrm{O}$ value was followed by a marked increase (Fig. 9), a trend similar to that for the same period in 1983. As in the previous summer, the relationship between general discharge and $\delta^{18} \mathrm{O}$ levels was apparent. The outburst of Kalvtjörna on 24 July had a significant effect on the $\delta^{18} \mathrm{O}$ content of water discharging from the glacier (Knudsen and Theakstone, 1988).

In 1985, Kalvtjörna drained before the start of the field season, and the lake basin remained empty throughout

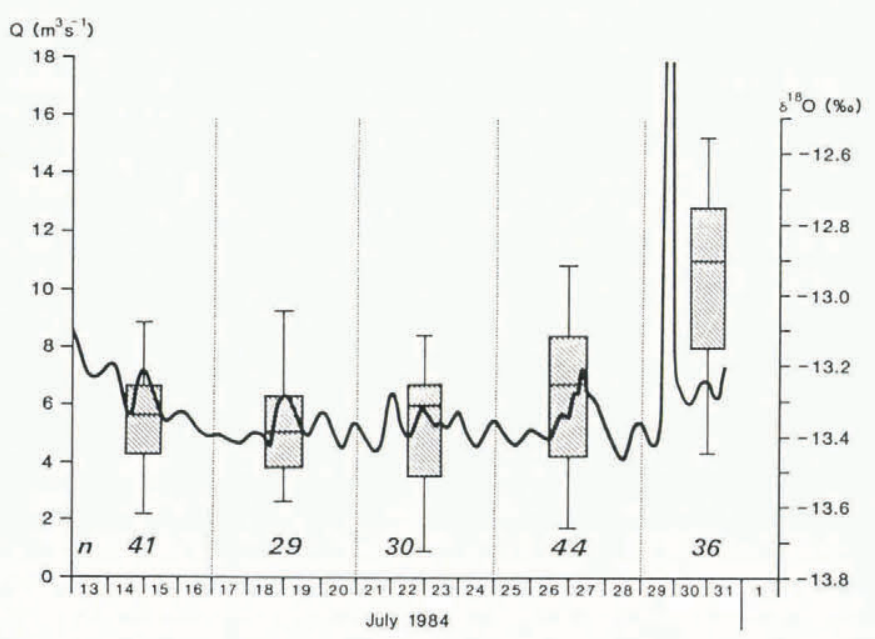

Fig. 9. Glacier-river discharge, and extreme, median, and quartile $\delta^{18} \mathrm{O}$ values of glacier river-water samples collected at Austre Okstindbreen during $4 d$ periods in July and August 1984. The number of samples (n) within each period is indicated. the period of river-water sampling. For the first part of the summer, the northern glacier river was smaller than was the southern one, and $\delta^{18} \mathrm{O}$ values from the latter (Table IV) were similar to those obtained from the northern river in previous years. The high $\delta^{18} \mathrm{O}$ values of samples collected from the northern river during the first part of the summer suggested that, unlike the larger river at the other side of the glacier, its discharge was dominated by water generated

TABLE IV. $\delta^{18} \mathrm{O}$ VALUES OF WATER SAMPLES COLLECTED FROM THE SOUTHERN GLACIER RIVER, AUSTRE OKSTINDBREEN, 7-12 JULY 1985

$\begin{array}{cccccc}\text { Minimum } & \begin{array}{c}\text { Lower } \\ \text { quartile }\end{array} & \text { Median } & \begin{array}{c}\text { Upper } \\ \text { quartile }\end{array} & \text { Maximum } & N \\ -13.84 & -13.66 & -13.50 & -13.45 & -12.99 & 15\end{array}$

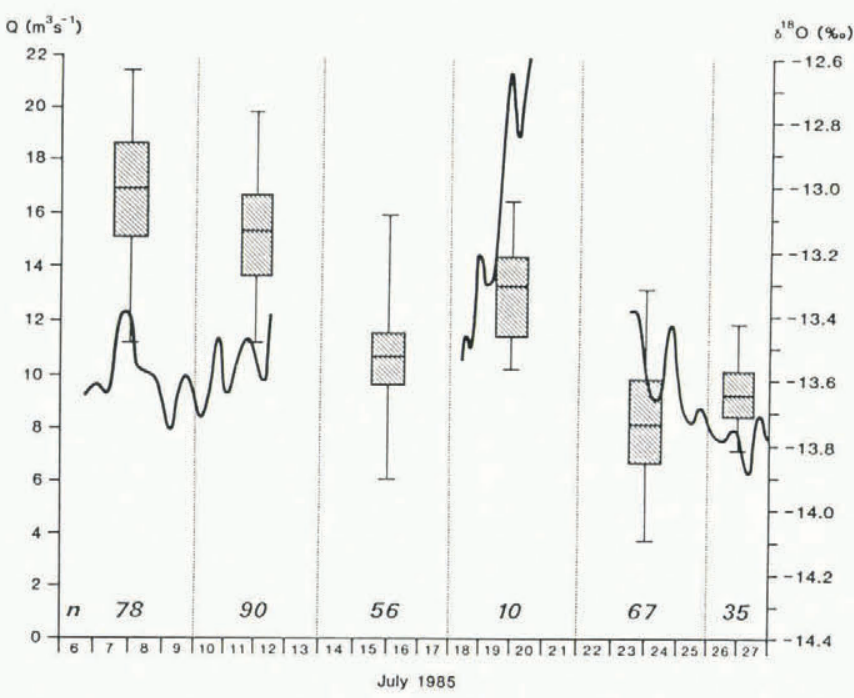

Fig. 10. Glacier-river discharge at site 1 (Fig. 1), and extreme, median, and quartile $\delta^{18} O$ values of water samples collected from the northern glacier river at Austre Okstindbreen in 1985. The number of samples ( $n$ ) within each period is indicated. Note that the summary statistics for 18-21 July are based on only ten samples. The discharge record was interrupted by equipment failures. Until 22 July, more water discharged in the southern river than in the northern one (see text for details); water from both rivers passed through site 1 . 


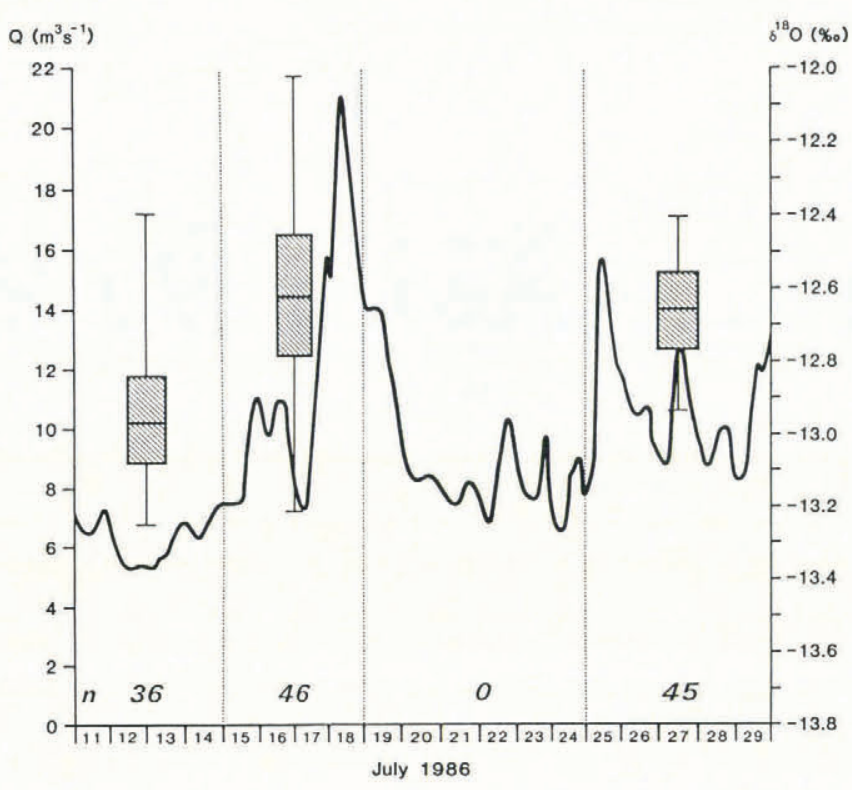

Fig. 11. Glacier-river discharge, and extreme, median, and quartile $\delta^{18} \mathrm{O}$ values of glacier river-water samples collected at Austre Okstindbreen in July 1986. The number of samples ( $n$ ) within each period is indicated. Sampling was interrupted between 18 and 25 July.

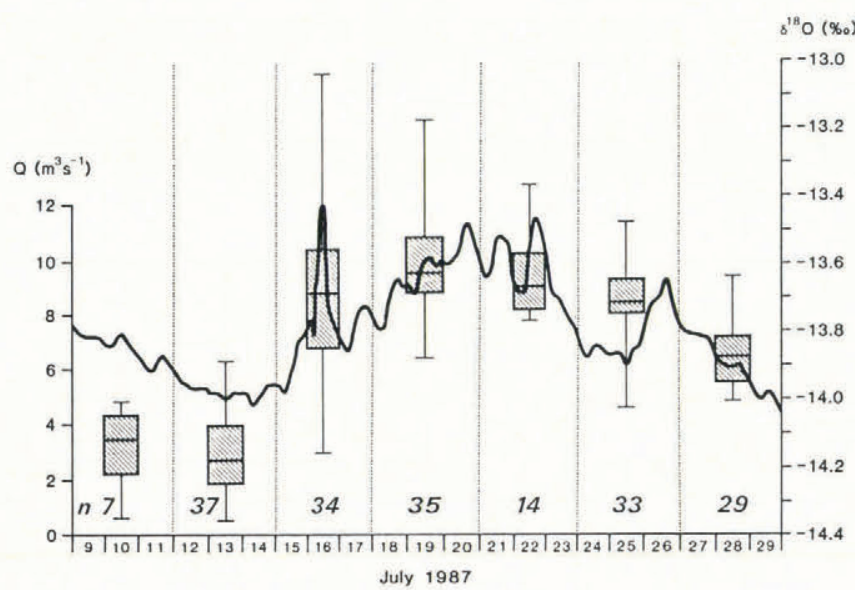

Fig. 12. Glacier-river discharge, and extreme, median, and quartile $\delta^{18} \mathrm{O}$ values of glacier river-water samples collected at Austre Okstindbreen during $3 d$ periods in July 1987. The number of samples ( $n$ ) within each period is indicated.

by relatively local surface melting. On 22 July 1985, during a storm, the southern glacier river ceased to flow, Thereafter, the northern river was the only major outlet of water from Austre Okstindbreen, and the base flow which previously had sustained flow of the southern river contributed to its discharge. In the circumstances, it was not surprising that the summer's overall pattern of $\delta^{18} \mathrm{O}$ values differed strikingly from that noted in previous years (Fig. 10). Samples collected on 23 and 24 July yielded the lowest $\delta^{18} \mathrm{O}$ values for river water in the 7 year period of sampling.

In 1986, the northern river again was the major outlet of water from the glacier. Kalvtjörna drained before the start of the field season. Heavy rainfall on 18 and 19 July resulted in high river discharge (Fig. 11). Sampling was interrupted in mid-July. As in the previous summer, the early-season drainage of Kalvtjörna must have left a major conduit between the lake basin and the glacier terminus, thereby facilitating drainage at a time when, in other circumstances, the systems within Austre Okstindbreen are relatively poorly developed.

In 1987 , the glacier-dammed lake outburst occurred on 16 July. At the beginning of the field season, when discharge was still influenced by melting of the previous winter's snow in the lower part of the catchment, $\delta^{18} \mathrm{O}$ values of glacier-river water were relatively low (Fig. 12). Subsequently, a general pattern of increasing median $\delta^{18} \mathrm{O}$ values until $20 \mathrm{July}$, and of decreasing values thereafter, was similar to the discharge trends.

\section{DISCUSSION}

Trends of $8^{18} \mathrm{O}$ variation of glacier-river water have been identified at two different scales - the hourly and the seasonal. The systematic patterns, and deviations from them, illuminate aspects of the operation of glacier-drainage systems.

During much of the summer, ice-melt water, relatively rich in ${ }^{18} \mathrm{O}$, and in transit for only a few hours, is responsible for diurnal variations of $\delta^{18} \mathrm{O}$ values in periods of fine weather, as it dilutes the base-flow component of discharge. The ${ }^{18} \mathrm{O}$-depleted base flow is a mixture of waters with different histories of formation, storage, and transit. Some is generated by accumulation-area melting: modelling (Svendsen, unpublished) and mass-balance studies (Knudsen, 1987) suggest that melt water generated above the $1200 \mathrm{~m}$ contour may contribute as much as $60-75 \%$ of the total flow of the principal Austre Okstindbreen glacier river during the summer season.

During the long winter season at Austre Okstindbreen, ground water in the near-surface recharge zone, and some water in firn, crevasses, and cavities freezes, becoming ${ }^{18} \mathrm{O}$-depleted. When winter ends and snow-melt water begins to discharge from the glacier, $\delta^{18} \mathrm{O}$ values are influenced by the isotopic composition of both the water stored within and beneath the glacier and the winter precipitation, which generally has low $\delta^{18} \mathrm{O}$ values, reflecting the prevailing low winter air temperatures. As surface melting proceeds, melt-water infiltration may cause a degree of ${ }^{18} \mathrm{O}$-enrichment of the snow-pack. Disappearance of the snow cover from the lower part of the tongue, accompanied by an increasing contribution of ice-melt water to discharge, therefore tends to be accompanied by a rise of $\delta^{18} \mathrm{O}$ values of glacier-river water. Throughout the summer, however, $\delta^{18} \mathrm{O}$ variations of bulk glacier water are related to discharge fluctuations, because of the dominance of the base-flow component. Melt water generated in the accumulation area helps maintain base flow of the principal river throughout the summer. Rivers issuing from the glacier to which base flow makes a smaller contribution are isotopically different to the principal river. It is probable that, in the accumulation area, melt water moves down through the porous firn to an aquifer of seasonally changing thickness, and becomes isotopically depleted as a result of exchange between ice and water (Oerter and others, 1985).

Drainage-system disruption by early-summer outbursts from Kalvtjörna, results in patterns of $\delta^{18} \mathrm{O}$ variations of glacier-river water which differ from those detectable in years when outbursts occur later in the season. Since the events leave a large open conduit within, or at the base of, the glacier, water may be transmitted rapidly through the glacier over a much longer distance than is usual in early July. Furthermore, the conduit perimeter is likely to include a considerable proportion of glacier ice. Once the lake outburst has ended, water flowing through the conduit causes ice to melt, adding ice-melt water to the discharge of the glacier river.

\section{CONCLUSIONS}

In comparison with water entering the glacier as a result of surface melting, that in the principal river discharging from Austre Okstindbreen is ${ }^{18} \mathrm{O}$-depleted: few sources with $\delta^{18} \mathrm{O}$ values as low as those of most riverwater samples have been identified. Depletion results from fractionation processes occurring betwen the times of precipitation on to the glacier surface and outflow from the tongue. Run-off from the ablation area is determined by the roles of ice-melt water moving from the surface to the point of river outflow, of water released from storage, of rainfall and of ground-water discharge. 
At the beginning of the ablation season, melting of the winter's snow-pack dominates river discharge, and is normally responsible for a characteristically low $8^{18} \mathrm{O}$ value. Subsequently, an increasing contribution of melting ice causes $\delta^{18} \mathrm{O}$ values to rise. Ice-melt water is also responsible for diurnal variations of isotopic composition of river water in periods of fine weather, as it moves quickly through the glacier's drainage systems,

Although the probability that seasonal trends of isotopic composition of glacier-river water will be repeated from one summer to another is high, changes of the glacier's drainage systems, including those related to outbursts of a glacier-dammed lake, may cause modifications. When two rivers issue from Austre Okstindbreen, the smaller is richer in the heavier isotope, ${ }^{18} \mathrm{O}$, than is the principal one; apparently, the second river is maintained more by ablation-area surface sources than by the ${ }^{18} \mathrm{O}$-depleted water which contributes the substantial base-flow component to the principal river.

\section{ACKNOWLEDGEMENTS}

Isotope analyses of samples collected at Okstindan since 1980 have been undertaken at the Copenhagen University Geophysical Isotope Laboratory, by arrangement with Professor W. Dansgaard and N. Gundestrup; I am very grateful for their contribution to the work of the Okstindan Glacier Project. The Project is a collaborative one, involving personnel from the University of Manchester, England, and the University of Aarhus, Denmark. I am grateful to all who have assisted in the collection of samples and in other field work at Okstindan, particularly Professor J.T. Möller, Lektor N.T. Knudsen, and post-graduate students O. Bendixen, C. Durbin, M. Jeffries, P. Reimann, and L. Svendsen. Financial support has been provided by the British Council, the U.K. Natural Environment Research Council, the Royal Society, and the University of Manchester. Cartographic advice and assistance from $\mathrm{N}$. Scarle has been of great value. Comments from anonymous referees on an earlier version did much to improve the quality of this paper.

\section{REFERENCES}

Ambach, W., and 6 others. 1976. Deuterium, tritium and gross-beta-activity investigations on Alpine glaciers (Ötztal Alps). J. Glaciol., 17(77), 383-400.

Ảrnason, B. 1981. Ice and snow hydrology. In Gat, J.R. and R. Gonfiantini, eds. Stable isotope hydrology. Deuterium and oxygen-18 in the water cycle. Vienna, International Atomic Energy Agency, 143-175.

Behrens, H., and 7 others. 1971. Study of the discharge of alpine glaciers by means of environmental isotopes and dye tracers. Z. Gletscherkd. Glazialgeol., 7(1-2), 79-102.

Bendixen, O. Unpublished. Energibalanceundersøgelse på Austre Okstindbre i Norge. Specialrapport. Aarhus Universitet. Geologisk Institut.

Braithwaite, R.J. and O.B. Olesen. 1984. Ice ablation in West Greenland in relation to air temperature and global radiation. Z. Gletcherkd. Glazialgeol., 20, 155-168.

Búason, Th. 1972. Equations of isotope fractionation between ice and water in a melting snow column with continuous rain and percolation. J. Glaciol., 11(63), 387-405.
Dansgaard, W. 1964. Stable isotopes in precipitation. Tellus, 16(4), 436-468.

Gat, J.R. 1980. The isotopes of hydrogen and oxygen in precipitation. In Fritz, P. and J.C. Fontes, eds. Handbook of environmental isotope geochemistry. Vol. I. Amsterdam and New York, Elsevier Scientific Publishing Co., 21-47.

Griend, A.A. van de and J.A. Arwert. 1983. The mechanism of runoff generation from an Alpine glacier during a storm traced by oxygen ${ }^{18} \mathrm{O} /{ }^{16} \mathrm{O}$. J. Hydrol., 62(1-4), 263-278.

Hambrey, M.J. 1974. Oxygen isotope studies at Charles Rabots Bre, Okstindan, northern Norway. Geogr. Ann., $56 \mathrm{~A}(3-4), 147-158$.

Knighton, A.D. and W.H. Theakstone. 1978. Throughflow water velocities in Austre Okstindbreen, Norway. J. Glaciol., 20(84), 598-599.

Knudsen, N.T. 1978. Drainage of an ice-dammed lake, Okstindan, Nordland, Norway. Nor. Geogr. Tidsskr., 32(2), 55-61.

Knudsen, N.T. 1987. Glacier variations and mass balance at Austre Okstindbre, Nordland, Norway. Okstindan Glacier Proj. Rep. 87.1.

Knudsen, N.T. and W.H. Theakstone. 1988. Drainage of the Austre Okstindbreen ice-dammed lake, Okstindan, Norway. J. Glaciol., 34(116), 87-94.

Moser, H. and W. Stichler. 1975. Deuterium and oxygen-18 contents as an index of the properties of snow covers. International Association of Hydrological Sciences Publication 114 (Symposium at Grenoble - Snow Mechanics), 122-135.

Moser, H. and W. Stichler. 1980. Environmental isotopes in snow and ice. In Fritz, P. and J.C. Fontes, eds. Handbook of environmental isotope geochemistry. Vol. I. Amsterdam and New York, Elsevier Scientific Publishing Co., 141-178.

Oerter, H., D. Baker, W. Stichler, and W. Rauert. 1985. Isotope studies of ice cores from a temperate Alpine glacier (Vernagtferner, Austria) with respect to the meltwater flow. Ann. Glaciol., 7, 90-93.

Reimann, P. Unpublished. Glacialt smeltevands kemiske karakteristiker ved Austre Okstindbre i Norge. Specialrapport. Aarhus Universitet. Geologisk Institut.

Röthlisberger, H. and H. Lang. 1987. Glacial hydrology. In Gurnell, A.M. and M.J. Clark, eds. Glacio-fluvial sediment transfer: an alpine perspective. Chichester, etc., John Wiley and Sons, 207-284.

Stichler, W. and A. Herrmann. 1977. Variations of isotopes in snow covers as input of temperate glaciers. $Z$. Gletscherkd. Glazialgeol., 13(1/2), 181-191.

Svendsen, L.M. Unpublished. Opbygning af en hydrologisk model for vandføringen i det glaciale smeltevandsløb fra Austre Okstindbre, Nordland, Norge. Specialrapport. Aarhus Universitet. Geologisk Institut.

Theakstone, W.H. 1978. The 1977 drainage of the Austre Okstindbreen ice-dammed lake, its cause and consequences. Nor. Geogr. Tidsskr., 32(4), 159-171.

Theakstone, W.H. 1986. Within-a-season trends of isotopic composition of glacier river water. Okstindan Glacier Proj. Rep. 86.4.

Theakstone, W.H. and C.S. Durbin. 1986. Oxygen isotope variations in glacier river water, Austre Okstindbreen, Okstindan, Norway. Okstindan Glacier Proj. Rep. 86.1.

Theakstone, W.H. and N.T. Knudsen. 1981. Dye tracer tests of water movement at the glacier Austre Okstindbreen, Norway. Nor. Geogr. Tidsskr., 35(1), 21-28. 